\title{
Restricted exposure of mice to primer pheromones coincident with prolactin surges blocks pregnancy by changing hypothalamic dopamine release*
}

\author{
A. E. Rosser, C. J. Remfry and E. B. Keverne $\dagger$ \\ Department of Anatomy, University of Cambridge, Downing Street, Cambridge CB2 3DY, UK
}

\begin{abstract}
Summary. Exposure of recently mated female mice to strange male urine revealed that exposure for $8 \mathrm{~h}$ was sufficient to produce pregnancy block providing exposure is for two 4-h periods coincident with prolactin surges. Exposure for $8 \mathrm{~h}$ between prolactin surges or one 4-h exposure coincident with either the nocturnal or the diurnal prolactin surge was without effect. When bromocriptine, a dopamine agonist, was given coincident with the nocturnal and diurnal prolactin surges, it was equally effective, but the opiate antagonist (naltrexone) administered in a similar manner was without effect. This result indicates that pheromonal action is through excitation of the tuberoinfundibular neurones rather than by inhibition of $\beta$-endorphin neurones. Further evidence for dopamine involvement in pregnancy block is demonstrated by showing DOPA accumulation in the medio-basal hypothalamus following exposure to male urinary pheromones after dihydroxybenzylhydrazine (DHBH) administration, which blocks the enzyme DOPA-decarboxylase. Taken together, this series of experiments provides convincing evidence for the dopamine inhibition of prolactin release being the final pathway for pheromone action in the context of pregnancy block.
\end{abstract}

Keyw'ords: pheromones; pregnancy block; critical exposure time; dopamine; mouse

\section{Introduction}

The reproductive biology of rodents is strongly influenced by chemical cues, both in the context of behaviour (signalling pheromones) and reproductive endocrinology (primer pheromones). An important effect of primer pheromones is observed in the female on the control of oestrus. This occurs in a number of species by controlling the onset of puberty (Vandenbergh, 1969) and the onset of oestrus after a period of anoestrus (Whitten, 1966). A special case of oestrus control which occurs in the mouse and a few other rodent species is the olfactory block to pregnancy. This was first described by Bruce (1959) who found that newly mated female mice returned to oestrus if they were exposed to strange males within $72 \mathrm{~h}$ of the initial mating. The fact that pregnancy block cannot occur after implantation suggests that the effect of male primer pheromones is on the preimplantation hormonal status. In both the block to pregnancy and the induction of oestrus, the primary endocrine change is a fall in serum prolactin (Reynolds \& Keverne, 1979; Ryan \& Schwartz, 1980; Keverne, 1982; Marchlewska-Koj, 1983).

Evidence that prolactin is the hormone mainly responsible for pregnancy block comes from experiments which show that suckling or injection of exogenous prolactin protect mice from the block (Bruce \& Parkes, 1960, 1961). Injection of the dopamine agonist, bromocriptine, which lowers prolactin concentration, also produces a block to pregnancy with a timing similar to that seen

\footnotetext{
*Reprint requests to Dr E. B. Keverne.

†Present address: Sub-Department of Animal Behaviour, University of Cambridge, Madingley, Cambridge CB3 8AA, UK.
} 
following introduction of a male (Bellringer et al., 1980). A fall in serum prolactin values has also been proposed as the cause of pregnancy block in the vole (Milligan, 1976; Charlton et al., 1978).

The central mechanism for the control of prolactin in the context of the olfactory block to pregnancy is unclear. The accessory olfactory system is known to mediate pregnancy block (LloydThomas \& Keverne, 1982) and this has a neural input via the corticomedial amygdala to the ventromedial hypothalamus (VMH) and medial preoptic area (MPOA), two areas of the brain involved in the control of the twice-daily surges of prolactin induced by coitus (Gunnet \& Freeman, 1984). Mating in the mouse and rat results in the secretion of two daily surges of prolactin, which consist of a nocturnal surge peaking about $1 \mathrm{~h}$ before lights on, and a diurnal surge peaking about $1 \mathrm{~h}$ before lights off (Butcher et al., 1972; Freeman et al., 1974; Smith et al., 1974; Barkley et al., 1978). As a result of these twice-daily surges of prolactin, the newly formed corpora lutea remain stable and secrete increasing amounts of progesterone from Days 1 to 8 of pseudopregnancy (Bartosik \& Szarowsk, 1973; de Greef \& Zeilmaker, 1979; Murakami et al., 1979).

While the primary endocrine changes in female mice following exposure to a male's pheromones appears to be prolactin, there are a number of hypothalamic factors known to influence prolactin release; dopamine, $\beta$-endorphin, GnRH-associated peptide and TRH being the most significant (McNeilly, 1986). TRH release occurs during suckling and appears to promote prolactin release, but only following a reduction in dopamine (Plotsky \& Neill, 1982; Leong et al., 1983). GnRHassociated peptide coexists with GnRH and is co-secreted in a pulsatile manner into hypophysial portal blood (Clarke et al., 1987) whence its effects on the pituitary are inhibitory to prolactin release (Nikolics et al., 1985). However, in the hypogonadal mouse, which is deficient in GnRH and GnRHassociated peptide (Mason et al., 1986), pituitary and plasma concentrations of prolactin are normal (Charlton et al., 1983). This leaves $\beta$-endorphin as a promoter of prolactin release and dopamine as an inhibitor of prolactin release as the most likely hypothalamic factors in the control of prolactin secretion in the context of pregnancy block. Previous studies have strongly implicated dopamine (Bellringer et al., 1980; Marchlewska-Koj, 1983) as the important factor in pregnancy block. However, studies of endogenous opiate antagonism by naloxone have demonstrated suppression of prolactin surges induced by mating as well as the spontaneous pro-oestrous prolactin surge (Sirinathsinghji \& Audsley, 1985). The present study investigates the role of $\beta$-endorphin and dopamine as hypothalamic factors controlling prolactin release in the context of the olfactory block to pregnancy. In addition, we have focussed on the critical timing of male pheromone exposure for producing pregnancy block and whether the $24-48 \mathrm{~h}$ continuous exposure is essential.

\section{Materials and Methods}

\section{Animals}

Adult male and virgin female BKT or BALB/c mice weighing approximately $25 \mathrm{~g}$ were housed singly in plastic cages with wood shavings as bedding. Temperature was controlled at $20 \pm 1^{\circ} \mathrm{C}$ and lighting was 12 -h light:12-h dark, with lights on at 06:00 h. Procedures conducted in the dark phase were done under red light. Food and water were available ad libitum. Adult males (hybrid F1 LAC $(\mathrm{CBA} \times \mathrm{C} 57 \mathrm{BL})$ were housed under similar conditions in another room and provided soiled bedding as a source of male primer pheromones. Mating was carried out naturally by placing a male of the same strain into the home cage of a singly housed female. Successful mating was indicated by the presence of a vaginal plug. The morning of finding the plug was designated as Day 1 of pregnancy, and the stud male was removed.

To demonstrate pregnancy block, mice were killed by cervical dislocation 6 days after mating and the uterine horns were examined for implantation sites. The absence of implantation sites confirmed a positive block to pregnancy.

\section{Procedures}

Experiment 1: optimal timing of pheromone exposure to induce pregnancy block. Freshly soiled bedding from strange males (F1 LAC) was introduced to the females' cages at various times after mating and for different durations before moving the female to a clean cage as follows: 
(a) $24 \mathrm{~h}$ exposure to strange male pheromones starting at 11:00 h or 02:00 h on Day 2;

(b) a single 4-h exposure to pheromone coincident with the nocturnal $(02: 00 \mathrm{~h})$ or diurnal $(17: 00 \mathrm{~h})$ prolactin surges on Day 2;

(c) two separate exposures to pheromone of 4-h duration coincident with the nocturnal $(02: 00 \mathrm{~h})$ and diurnal $(17: 00 \mathrm{~h})$ surges of prolactin on Day 2, or two separate exposures of 4-h duration, between prolactin surges;

(d) two separate 4-h exposures to pheromone coinciding with only the nocturnal prolactin surges on Days 2 and 3 , or two separate 4-h exposures coinciding with the diurnal surges on Days 2 and 3;

(e) no exposure to strange male pheromones; a control procedure for handling and estimating spontaneous abortion.

Experiment 2: effects of dopamine agonist or opiate antagonist on pregnancy block. Mating was carried out according to the procedure outlined above, but instead of introducing pheromones to the female, she was given the dopamine agonist ( $2 \mathrm{mg} \alpha$-bromocriptine/kg i.p.; Sandoz Ltd, Basle, Switzerland) or the opiate antagonist ( $2 \mathrm{mg}$ or $4 \mathrm{mg}$ naltrexone/kg, i.p.; Sterling Winthrop, Guildford, Surrey, UK). Drug was given in two doses, each coincident with the onset of the prolactin nocturnal and diurnal peaks on Day 2. Control procedures involved saline administration at these times or drug administration given between the prolactin surges on Day $2(06: 00 \mathrm{~h}$ and 21:00 h). Pregnancy block was assessed as outlined above.

Experiment 3: changes in hypothalamic dopamine release after exposure to male pheromones. A knowledge of the precise timing for pheromone exposure for induction of pregnancy block has enabled measurement of hypothalamic dopamine activity to be undertaken. An indirect assessment of dopamine synthesis was assessed by measuring DOPA accumulation following administration of dihydroxybenzylhydrazine (DHBH) which blocks the enzyme DOPA decarboxylase.

On the morning after mating females were housed singly according to three groupings; a control group received saline, a second group received the drug DHBH, and a third group received the drug DHBH and odour exposure. DHBH was administered in all cases by intraperitoneal injection $(2.5 \mathrm{mg}$ in $0.2 \mathrm{ml}) 30 \mathrm{~min}$ before the killing of animals for brain dissection. The odour-exposed groups had male pheromones introduced for $4 \mathrm{~h}$ starting at $02: 00 \mathrm{~h}$ to coincide with the nocturnal peak or for $17 \mathrm{~h}$ starting at $02: 00 \mathrm{~h}$ to coincide with the nocturnal and diurnal prolactin peaks. Each group contained 7 animals and samples were individually measured.

Hypothalamic punches ( $1 \mathrm{~mm}$ diameter) were taken from $500 \mu \mathrm{m}$ brain slices on a cooling plate, and included the arcuate nucleus and median eminence, hence ensuring collection of tuberohypophysial dopaminergic neurones and their terminals for measurement of DOPA accumulation. Pituitaries were taken for measurement of dopamine.

Brain tissue was cooled immediately on removal and stored at $-70^{\circ} \mathrm{C}$ until assayed. The tissue sample was homogenized in perchloric acid, centrifuged and the supernatant injected directly onto an h.p.l.c. column.

Dopamine and DOPA were measured using h.p.l.c. separation with electrochemical detection (Keller et al., 1976). Separation of compounds from the brain extract was accomplished by ion pair chromatography with a packing of octadecylsilane bonded onto $3-\mu \mathrm{m}$ silica particles. The flowing buffer contained aqueous heptane sulphonic acid and polarity was adjusted with an organic modifier (methanol) to achieve optimal separation. A glassy carbon electrode served as detector with following oxidation of amines at $0 \cdot 7-0 \cdot 8 \mathrm{~V}$.

\section{Statistical analysis}

Data from Exps 1 and 2 were analysed using information statistic (Robbins, 1977). This procedure allows the analysis of data with small cell frequencies which cannot be analysed by using $\chi^{2}$ tests. Information statistic has an identical distribution to $\chi^{2}$ and these tables are used to assess confidence limits. Changes in DOPA accumulation were measured by ANOVA, and dopamine release by Student's $t$ test.

\section{Results}

\section{Optimal timing for pheromone exposure to induce pregnancy block}

Exposure of mated females to strange male pheromones for $24 \mathrm{~h}$ starting on Day 2 at 02:00 h or 11:00 h produced a significant block to pregnancy when compared to control females not exposed to strange males (Table 1). A single 4-h exposure to strange male pheromones coincident with either the nocturnal or the diurnal prolactin peak did not induce a significant pregnancy block, while pheromone exposure coincident with both peaks was effective (Table 1). This is in contrast to an 8-h exposure to pheromones between prolactin surges or two separate 4-h exposures to pheromones that did not coincide with the prolactin peaks (Table 1).

Two separate exposures for $4 \mathrm{~h}$ which coincided with only the nocturnal prolactin surges on Days 2 and 3 after mating did not produce a pregnancy block, while exposure to pheromones for $2 \times 4$ h coincident with diurnal surges on Days 2 and 3 after mating produced a significant pregnancy block (Table 1). 
Table 1. Effects of pheromone exposure coincident with or between nocturnal $(02: 00 \mathrm{~h})$ and diurnal $(17: 00 \mathrm{~h})$ prolactin surges

\begin{tabular}{|c|c|c|c|c|}
\hline \multicolumn{2}{|c|}{ Pheromone exposure } & \multirow{3}{*}{$\begin{array}{c}\text { No. of } \\
\text { mice }\end{array}$} & \multirow{2}{*}{\multicolumn{2}{|c|}{$\begin{array}{l}\text { Pregnancy } \\
\text { block }\end{array}$}} \\
\hline Starting time & Duration & & & \\
\hline (h) & (h) & & No. & $\%$ \\
\hline 02:00 & 24 & 10 & 9 & 90 \\
\hline $11: 00$ & 24 & 9 & 9 & 100 \\
\hline No exposure & 0 & 9 & 1 & 11 \\
\hline 02:00 & 4 & 10 & 2 & 20 \\
\hline $17: 00$ & 4 & 10 & 1 & 10 \\
\hline $02: 00$ and $17: 00$ & 4 and 4 & 10 & $8^{*}$ & $80^{*}$ \\
\hline $\begin{array}{c}12: 00 \text { and } 21: 00 \\
\text { and } 12: 00\end{array}$ & $\begin{array}{l}4 \text { and } 4 \\
\text { and } 4\end{array}$ & 10 & 0 & 0 \\
\hline 08:00 & 8 & 10 & 1 & 10 \\
\hline 02:00 and 02:00 & 4 and 4 & 10 & 1 & 10 \\
\hline $17: 00$ and $17: 00$ & 4 and 4 & 10 & $8^{*}$ & $80^{*}$ \\
\hline
\end{tabular}

*Indicates pregnancy block significantly greater than no exposure but not different from controls receiving $24 \mathrm{~h}$ of pheromone exposure. $P<0 \cdot 05$, information statistic.

\section{Effects of dopamine agonist or opiate antagonist on pregnancy block}

Administration of bromocriptine on Day 2 after mating at times coincident with the prolactin peaks $(02: 00$ and 17:00 h) produced a significant block to pregnancy (Table 2). Injections of saline or naltrexone at the same time were without effect on pregnancy, as was the injection of the dopamine agonist when given following the decline in the nocturnal and diurnal prolactin surges (Table 2).

Table 2. Effects of dopamine agonist or $\beta$-endorphin antagonist administered coincident with prolactin surges on pregnancy block

\begin{tabular}{|c|c|c|c|c|}
\hline \multirow[b]{2}{*}{ Drug } & \multirow{2}{*}{$\begin{array}{l}\text { Starting } \\
\text { time } \\
\text { (h) }\end{array}$} & \multirow{2}{*}{$\begin{array}{l}\text { No. } \\
\text { of } \\
\text { mice }\end{array}$} & \multicolumn{2}{|c|}{$\begin{array}{l}\text { Pregnancy } \\
\text { block }\end{array}$} \\
\hline & & & No. & $\%$ \\
\hline $\begin{array}{l}\text { Bromocriptine } \\
(2 \mathrm{mg} / \mathrm{kg} \text { i.p. })\end{array}$ & $\begin{array}{l}02: 00 \text { and } \\
17: 00\end{array}$ & 10 & $9^{*}$ & $90^{*}$ \\
\hline $\begin{array}{l}\text { Bromocriptine } \\
(2 \mathrm{mg} / \mathrm{kg} \text { i.p. })\end{array}$ & $\begin{array}{c}06: 00 \text { and } \\
21: 00\end{array}$ & 10 & 1 & 10 \\
\hline Saline & $\begin{array}{c}02: 00 \text { and } \\
17: 00\end{array}$ & 10 & 1 & 10 \\
\hline $\begin{array}{l}\text { Naltrexone } \\
\quad(2 \mathrm{mg} / \mathrm{kg} \text { i.p. })\end{array}$ & $\begin{array}{l}02: 00 \text { and } \\
17: 00\end{array}$ & 10 & 2 & 20 \\
\hline $\begin{array}{l}\text { Naltrexone } \\
\quad(4 \mathrm{mg} / \mathrm{kg} \text { i.p. })\end{array}$ & $\begin{array}{l}02: 00 \text { and } \\
17: 00\end{array}$ & 10 & 3 & 30 \\
\hline
\end{tabular}

*Indicates significant pregnancy block, but not differing from controls receiving $24 \mathrm{~h}$ pheromone exposure. $P<0 \cdot 05$, information statistic.

\section{DOPA accumulation after $\mathrm{DHBH}$ and exposure to male pheromones}

When female mice were exposed to male pheromones for $4 \mathrm{~h}$ coincident with the nocturnal prolactin peak there was no significant increase in DOPA accumulation over and above that found in females receiving the DOPA decarboxylase inhibitor (DHBH) without pheromone exposure (Table 3). Analysis of variance for hypothalamic DOPA accumulation showed there to be a significant difference between groups $(F=90 \cdot 17, \mathrm{~V} 1=2, \mathrm{~V} 2=13, P<0.001)$ but Duncan's test 
revealed these differences to be between drug treatment and controls, with no difference between pheromone and no pheromone groups.

When female mice were exposed to male pheromones for $17 \mathrm{~h}$ which coincided with both diurnal and nocturnal prolactin peaks, ANOVA for hypothalamic DOPA accumulation revealed a significant effect across groups $(\mathrm{F}=59 \cdot 4, \mathrm{~V} 1=2, \mathrm{~V} 2=12, P<0.0001)$. Duncan's test showed the drug treated groups to be different from the non-drug treated groups and the group exposed to pheromones to have a significantly higher accumulation of DOPA than the non-exposed group (Table 3 ).

Table 3. Hypothalamic DOPA levels (ng/hypothalamic punch) after pheromone exposure and dihydroxybenzylhydazine $(\mathrm{DHBH})$ treatment

\begin{tabular}{lcccc}
\hline \multicolumn{2}{c}{ Pheromone exposure } & & & \\
\cline { 1 - 2 } \multicolumn{1}{c}{ Time } & Duration $(\mathrm{h})$ & Saline & DHBH & $\begin{array}{c}\text { Pheromone } \\
\text { DHBH }\end{array}$ \\
\hline $02: 00 \mathrm{~h}$ & 4 & $0.69 \pm 0.7$ & $1.81 \pm 0.17$ & $1.75 \pm 0.15$ \\
$02: 00 \mathrm{~h}$ & 17 & $0.46 \pm 0.18$ & $2.90 \pm 0.24$ & $3.77 \pm 0.20^{*}$ \\
$\begin{array}{l}\text { Pituitary } \\
\text { dopamine }\end{array}$ & & $0.44 \pm 0.07$ & $0.40 \pm 0.06$ & $0.38 \pm 0.05$ \\
\hline
\end{tabular}

*Significantly higher than values for drug treatment without pheromone exposure (F $=59 \cdot 4$, df $2,12, P<0.0001$ ).

Values are mean \pm s.e.m.

No significant differences were found for pituitary dopamine across groups $(\mathrm{F}=0.04, \mathrm{VI}=2$, $\mathrm{V} 2=15, \mathrm{NS})$.

\section{Discussion}

After mating, prolactin concentrations in the female mouse rise (Sinha et al., 1978) to provide luteotrophic support, enabling the corpus luteum to release progesterone and hence prime the uterus for implantation (Smith \& Neill, 1976). However, in early pregnancy, the prolactin concentrations in the female mouse are not constantly elevated; the luteotrophic support is driven by two daily surges of prolactin (Barkley et al., 1978). In the rat the diurnal prolactin surge is already present in the afternoon of pro-oestrus and continues in synchrony with photoperiod (Bethea \& Neill, 1980) while the nocturnal prolactin surge occurs as part of a neuroendocrine reflex associated with copulation (Freeman et al., 1974). Since pheromonal exposure has its effects via prolactin release, the question arises as to the necessity for $48 \mathrm{~h}$ exposure in order to bring about the pregnancy block. This study has considered the importance of pheromone exposure only at the reported time of prolactin surges and it reveals that two 4-h pheromone exposures at surge times are as effective as exposure for $24 \mathrm{~h}$. Exposure to pheromone for $8 \mathrm{~h}$ between prolactin surges or three separate 4-h exposures between prolactin surges are ineffective. Exposure to male pheromones for only $4 \mathrm{~h}$ at either the nocturnal or the diurnal prolactin surge is without effect on pregnancy block, as is two $4 \mathrm{~h}$ exposures to only nocturnal surges $24 \mathrm{~h}$ apart. However, two 4 -h exposures at the time of the diurnal prolactin surges on Days 2 and 3 after mating were found to be as effective in producing pregnancy block as continuous exposure for $24 \mathrm{~h}$. The diurnal prolactin surge is larger than the nocturnal surge in mice (Barkley et al., 1978) and is probably of considerable importance at this stage for the secondary elevation of progesterone concentrations (Smith \& Neill, 1976). These results confirm that primer pheromones produce their effect on pregnancy block by inhibiting prolactin release. Exposure to pheromones coincident with these prolactin surges is sufficient to produce pregnancy block, and the diurnal surges would appear to be of more significance in this context than nocturnal surges. 
Inhibition of hypothalamic opiate release is known to suppress the elevated concentrations of prolactin associated with stress (Grandison \& Guidotti, 1977) while the pro-oestrous surge in prolactin is also subject to suppression by opiate receptor blockade in the rat (Ieiri et al., 1980). There is therefore the potential for opiate release to function in the context of pregnancy block. However, in this study we were not able to induce pregnancy block by the opiate receptor blocker, naltrexone, administered coincident with prolactin surges. Moreover, direct measurement of hypothalamic $\beta$-endorphin in recently mated mice gave values no different from those in unmated controls (unpublished findings). This was in marked contrast to findings we report here for the dopaminergic control of pregnancy block. Two small injections of the dopamine agonist bromocriptine $(50 \mu \mathrm{g})$ coincident with the prolactin surges was just as effective as male pheromone exposure in blocking pregnancy. This same dose of bromocriptine given between prolactin surges was without effect on pregnancy block.

Further evidence for dopamine involvement in pheromone-induced pregnancy block came from the measurement of increased DOPA accumulation after presentation of strange male odours to newly mated females. This measurement was taken during the estimated time of the nocturnal prolactin peak (McKay et al., 1982) and exposure was for a greater period than in other experiments. The accumulation of DOPA is thought to occur primarily in dopaminergic neurones as the rate of synthesis of the catecholamine noradrenaline accounts for $<10 \%$ of the total catecholamine synthesis in the median eminence (Demarest et al., 1979). The tissue assayed in the present study contained cell bodies of the tuberohypophysial dopaminergic neurones in the anterior part of the arcuate nucleus, and both terminals and cell bodies of these neurones. As DOPA synthesis occurs in catecholamine terminals, DOPA accumulation in this dissection is likely to be a good representation of tuberohypophysial dopaminergic neurone activity. It would have been instructive to measure both DOPA accumulation and dopamine depletion in one sample after DHBH administration. However, this was not technically possible since DOPA eluted long before dopamine, making the dopamine peak very broad and therefore inaccurate. Splitting the samples would have rendered DOPA undetectable in individual samples. Although differences were found in hypothalamic DOPA accumulation with exposure to odour for $17 \mathrm{~h}$, no differences were found in pituitary contents of dopamine between drug-treated groups or non-drug-treated groups. One interpretation of this finding is that the releasable pool of dopamine is small and so differences in dopamine values cannot be measured in the pituitary once synthesis has been prevented.

Taking the evidence for increased dopamine synthesis following pheromone exposure, and the effectiveness of a dopamine agonist on pregnancy block, these results point to the tuberohypophysial dopaminergic neurones as the final mediator of pheromonally induced prolactin changes.

This work was supported by a MRC project grant to E.B.K.

\section{References}

Barkley, M.S., Bradford, G.E. \& Geschwind, I.I. (1978) The pattern of plasma prolactin concentration during the first half of mouse gestation. Biol. Reprod. 19, 291-296.

Bartosik, D. \& Szarowsk, D.H. (1973) Progravid phase of the rat reproductive cycle: day to day changes in peripheral progestin concentrations. Endocrinology 92, 949-952.

Bellringer, J.F., Pratt, H.P.M. \& Keverne, E.B. (1980) Involvement of the vomeronasal organ and prolactin in pheromonal induction of delayed implantation in mice. J. Reprod. Fert. 59, 223-228.

Bethea, C.L. \& Neill, J.D. (1980) Lesions of the suprachiasmatic nuclei abolish the cervically stimulated prolactin surges in the rat. Endocrinology 107, 1-5.
Bruce, H.M. (1959) An exteroceptive block of pregnancy in the mouse. Nature, Lond. 184, 105.

Bruce, H.M. \& Parkes, A.S. (1960) Hormonal factors in the exteroceptive block to pregnancy in mice. $J$. Endocr. 20, 29-30.

Bruce, H.M. \& Parkes, A.S. (1961) An olfactory block of implantation in mice. J. Reprod. Fert. 2, 195-196, abstr.

Butcher, R.L., Fugo, N.W. \& Collins, W.E. (1972) Semi circadian rhythm in plasma levels of prolactin during early gestation in the rat. Endocrinology 90, 1125-1127.

Charlton, H.M., Milligan, S.R. \& Versi, E. (1978) Studies on the control of the corpus luteum in the vole Microtus agrestis. J. Reprod. Fert. 52, 283-288. 
Charlton, H.M., Speight, A., Halpin, D.M.G., Bramwell, A., Sheward, W.J. \& Fink, G. (1983) Prolactin measurements in normal and hypogonadal (hpg) mice: developmental and experimental studies. Endocrinology 108, 2359-2366.

Clarke, I.J., Cummins, J.T., Karsch, F.J., Seeburg, P.H. \& Nikolarics, K. (1987) GnRH associated peptide (GAP) is cosecreted with $\mathrm{GnRH}$ into the hypophyseal portal blood of ovariectomised sheep. Biochem. Biophys. Res. Commun. 143, 665-671.

De Greef, W.J. \& Zeilmaker, G.H. (1979) Serum prolactin concentrations during hormonally induced pseudopregnancy in the rat. Endocrinology 105, 195-199.

Demarest, K.T., Alper, R.H. \& Moore, K.E. (1979) DOPA accumulation is a measure of dopamine synthesis in the median eminence and posterior pituitary. $J$. neural Trans. 46, 183-193.

Freeman, M.E., Smith, M.S., Nazian, J. \& Neill, J.D. (1974) Ovarian and hypothalamic control of the daily surges of prolactin secretion during pseudopregnancy in the rat. Endocrinology 94, 875-882.

Grandison, L. \& Guidotti, A. (1977) Regulation of prolactin release by endogenous opiates. Nature, Lond. 270, 357-359.

Gunnet, J.W. \& Freeman, M.E. (1984) Hypothalamic regulation of mating-induced prolactin release: effect of electrical stimulation in the medial preoptic area in conscious female rats. Neuroendocrinology 38, 12-16.

Ieiri, T., Chen, H.T., Campbell, G.A. \& Meites, J. (1980) Effects of Naloxone and morphine on the proestrous surge of prolactin and gonadotropins in the rat. Endocrinology 106, 1568-1570.

Keller, R., Oke, A., Mefford, I. \& Adams, R.N. (1976) Liquid chromatographic analysis of catecholamines. Routine assay for regional brain mapping. Life Sci. 19, 995-1004.

Keverne, E.B. (1982) The accessory olfactory system and its role in pheromonally mediated changes in prolactin. In Olfaction and Endocrine Regulation, pp. 127-140. Ed. W. Breiphol. IRL Press, London.

Leong, D.A., Frawley, S. \& Neill, J.D. (1983) Neuroendocrine control of prolactin secretion. Ann. Rev. Physiol. 45, 109-127.

Lloyd-Thomas, A. \& Keverne, E.B. (1982) Role of the brain and accessory olfactory system in the block to pregnancy in mice. Neuroscience 7, 907-913.

Marchlewska-Koj, A. (1983) Pregnancy blocking by pheromones. In Pheromones and Reproduction in Mammals, pp. 113-174. Ed. J. G. Vandenbergh. Academic Press, New York.

Mason, A.J., Hayflick, J.S., Zoeller, R.T., Young, W.S., Phillips, H.S., Nikolics, K. \& Seeburg, P.H. (1986) A deletion truncating the gonadotrophin releasing hormone gene is responsible for hypogonadism in the hpg mouse. Science, NY 234, 1366-1371.

McKay, D.W., Pasleka, C.A., Moore, K.E., Riegle, G.D. \& Demarest, K.T. (1982) Semicircadian rhythm of TIDA activity during early pregnancy and pseudopregnancy in the rat. Neuroendocrinology 34, 229-235.
McNeilly, A.S. (1986) Prolactin. In Neuroendocrinology, pp. 538-562. Eds S. L. Lightman \& B. J. Everitt. Blackwell, Oxford.

Milligan, S.R. (1976) Pregnancy blocking in the vole Microtus agrestis. II. Ovarian, uterine and vaginal changes. J. Reprod. Fert. 46, 97-100.

Murakami, N., Takahashi, M. \& Suzuki, Y. (1979) Indispensable role of peripheral progesterone levels for the occurrence of prolactin surges in pseudopregnant rats. Biol. Reprod. 21, 263-268.

Nikolics, K., Mason, A.J., Szonyi, E., Ramachandran, J. \& Seeburg, P.H. (1985) A prolactin inhibiting factor within the precursor for human gonadotrophinreleasing hormone. Nature, Lond. 316, 511-517.

Plotsky, P.M. \& Neill, J.D. (1982) Interactions of dopamine and thyrotrophin releasing hormone in the regulation of prolactin release in lactating rats. Endocrinology 111, 168-173.

Reynolds, J.M. \& Keverne, E.B. (1979) The accessory olfactory system and its role in pheromonally-mediated suppression of oestrus. J. Reprod. Fert. 57, 31-33.

Robbins, T.W. (1977) A critique of the methods available for the measurement of spontaneous activity. In Handbook of Psychopharmacology, pp. 32-38. Eds L. L. Iverson, S. D. Iverson \& S. H. Snyder. Plenum Press, New York.

Ryan, K.D. \& Schwartz, N.B. (1980) Changes in serum hormone levels associated with male-induced ovulation in group-housed female mice. Endocrinology 106, 959-966.

Sinha, Y.N., Wickes, M.A. \& Baxter, S.R. (1978) Prolactin and growth hormone secretion and mammary gland growth during pseudopregnancy in the mouse. J. Endocrin. 77, 203-212.

Sirinathsinghji, D.J.S. \& Audsley, A.R. (1985) Endogenous opioid peptides participate in the modulation of prolactin release in response to cervico-vaginal stimulation in the female rat. Endocrinology 117, 549-556.

Smith, M.S. \& Neill, J.D. (1976) Termination at midpregnancy of the two daily surges of plasma prolactin initiated by mating in the rat. Endocrinology 98, 696-701.

Smith, M.S., Freeman, M.E. \& Neill, J.D. (1974) The control of prolactin secretion during the estrous cycle and early pseudopregnancy in the rat: prolactin gonadotrophin and steroid levels associated with rescue of the corpus luteum of pseudopregnancy. Endocrinology 96, 219-226.

Vandenbergh, J.G. (1969) Male odour accelerates female sexual maturation in mice. Endocrinology 84, 658-660.

Whitten, W.K. (1966) Pheromones and mammalian reproduction. In Advances in Reproductive Physiology, Vol. 1, pp. 155-177. Ed. A. McLaren. Academic Press, New York.

Received 20 February 1989 